\title{
IMPACT OF BUFFALO DAMS TREATMENT WITH PROBIOTICS ON GROWTH PERFORMANCE, IMMUNE RESPONSES AND BLOOD COMPONENTS OF THEIR NEW BORN CALVES
}

\author{
H. A. El-Nagar ${ }^{1 *}$, A.M. El-Hais ${ }^{2}$ and M.S. Farag ${ }^{2}$ \\ 1-Department of biotechnology, Animal Production Research Institute, Agricultural Research Center, Dokki, \\ Giza, Egypt,2-Department of Animal Production, Faculty of agriculture, Tanta University, Egypt. \\ *Corresponding Author's E-mail: elnagar1970@hotmail.com, Cellular phone +201066315955
}

Received: 08/07/2020

Accepted: 03/09/2020

\section{SUMMARY}

This work aimed to identify the relationship between performance, immune system and blood components of neonatal buffalo calves as affected by their dam treatments (DT) with or without probiotic cultures. 40 Egyptian buffalo cows were used in this study. Dams were classified into 4 treatment groups, G1 as control group without any treatment, Saccharomyces cerevisiae yeast culture (20 g/h/d, YC, G2) group, Lactobacillus acidophilus (20 $\mathrm{g} / \mathrm{h} / \mathrm{d}, \mathrm{LB}, \mathrm{G3})$ group, or the half dose of each as a combination (G4). The experimental period was 30-d pre-till 105-d postpartum. Results revealed that, the dams treated with YC and LB combination (G4), has the best growth performance during birth and weaning, by increasing calf total gain by $31.7 \%$ relative to the control group and the immunoglobulins (IgG, IgA and IgM) concentrations in calf plasma and colostrum, during the first three days after calving. All hematological parameters (RBCs count, PCV percentage and Hb concentration), as well as plasma metabolites (total proteins, albumin, globulin, total lipids, total cholesterol and glucose concentrations) increased $(P<0.05)$, while WBCs and creatinine decreased $(P<0.05)$ in calves of treatment groups as compared to control one, being the best in $G 4$ calves. Total antioxidant capacity and triiodothyronine concentration increased $(P<0.05)$, while AST and ALT activity decreased $(P<0.05)$ in calves of treatment groups as compared to control one, being the best in G4 calves. There were highly significant and strong correlation coefficients (r) between immunoglobulins in calf plasma and colostrum. In conclusion, dietary addition of Saccharomyces cerevisiae $(10 \mathrm{~g} / \mathrm{h} / \mathrm{d})$ and Lactobacillus acidophiolus $(10 \mathrm{~g} / \mathrm{h} / \mathrm{d})$ combination in the diets of Egyptian buffalos 30-d pre- up to 105-d post-partum improved growth performance, immunity response, blood hematology, metabolites, antioxidant capacity, enzyme activity and T3 hormone of the newborn calves.

Keywords: Calves, probiotic; immunoglobulines, hematology, metabolites, enzymes, T3, Egyptian buffalos

\section{INTRODUCTION}

Calf's performance is a critical factor linked to the economics of intensive breeding, since health on the first weeks of life strictly linked not only to the mortality rate but also to the impact on morbidity with increased antibiotic and feed costs. During the 1st month of life, calves possess an extremely unstable intestinal microbiota and are susceptible to the proliferation of microorganisms that frequently lead to gastrointestinal diseases, particularly diarrhea, which led to reduce nutrients digestion and absorption (Agazzi et al., 2014).

The newborn calf is essentially a monogastric animal and weaning at an early age decreases new born calf's resistance to bacterial infections and impairs growth performance (Soderholm and Perdue, 2001). Several investigators have found that average daily gain (ADG) during suckling period has positive effects on the long-term productivity of dairy calves (Soberon and Van Amburgh, 2013).

Feed additives can improve animal gut health and increase the digestion rate and improve growth performance (Kawakami et al., 2010; Frizzo et al., 2011). A probiotic is defined as a live microbial feed supplement, which beneficially affects the host animal by improving its intestinal microflora. The genera of yeast and lactobacilli are one of the most commonly used probiotics in food products. The mechanism of action of a probiotic depends on the rumen microbial population. Yeast cells contain different vitamins, enzymes and some unidentified cofactors that may improve the microbial activity and growth rate in the rumen (Dawson, 1993).

In dairy and pharmaceutical products, lactobacillus acidophilus strains are widely used as probiotic cultures because the strain is one of the dominant lactobacilli in the human intestine $(\mathrm{Oh}$ et al., 2000). Many researchers reported that yeast culture improved feed intake (Ayad et al., 2013); feed conversion efficiency, growth rate (Lascano et al., 2009) and nutrient digestibility (Wohlt et al., 1991) in cost-effective manners (Hutjens, 2003). Yeast also has positive effects on blood hematology resulting in improvement in the health status of the animals (Agazzi et al., 2014). Moreover, yeast supplementation increases the hemicelluloses degradability and some important nutrient digestibility (Lascano et al., 2012), also has positive effects on the absorption of some minerals (Cole et al., 1992) and improves animal metabolic heath (Dolezal et al., 2012). Previous studies have shown that the addition of probiotics to animal diets can improve mucosal immune system function. 
Particularly, probiotic supplementation can increase levels of immunoglobulin (Heinrichs et al., 2009).

In calves, researches on the effects of prebiotics are primarily limited to easily obtained physical measurements, such as average daily gain and fecal scoring (Heinrichs et al., 2009). Also, Bayram et al. (2016) reported an association between colostrum intake and calf blood immunoglobulin and biochemical levels. Also, Šlosarkova et al. (2011) found that colostrum intake had a relationship with the concentration of antibodies.

Therefore, the objective of this study was to evaluate the impact of buffalo dams treatment during pre- and post-partum period with probiotic (Saccharomyces cerevisiae and Lactobacillus acidophilus or their combination) on growth performance, immunity and blood components of their neonatal calves.

\section{MATERIALS AND METHODS}

The present study was conducted at Buffalo Dairy Farm which located in the middle delta of the Animal Production Research Station, El-Gemmezah, of Egypt. A total number of 40 lactating Egyptian buffaloes (500-600 kg live body weight(LBW) and $2^{\text {nd }}-4^{\text {th }}$ parity) at the late gestation period ( 30 days prepartum) based on the expected date of parturition were used. All dam animals were in good health status and clinically free of parasites. Animals were allocated to 4 similar groups (10/group) at the beginning of the experiment according to their body weight, milk yield and body conformation in the previous season. All pregnant dams were kept under the same managerial condition during the late pregnancy period. After calving, colostrum from their dams were given to all calves as soon as possible then it continued for three successive days.

\section{Feeding system of dams:}

In all groups, buffalo dams were fed ration composed of $60 \%$ concentrate feed mixture (CFM; $37 \%$ yellow corn, $30 \%$ undecorticated cotton seed, $20 \%$ wheat bran, $6.5 \%$ rice bran, $3 \%$ molasses, $2.5 \%$ limestone and $1 \%$ common salt), 20\% Egyptian clover (Trifolium alexandrinum) and 20\% wheat straw according to Kearl (1982). Animals were fed with the CFM individually twice daily at 6 a.m. and 5 p.m., while clover and wheat straw were offered at 8 a.m. and 4 p.m. Clean water was always available to animals. Chemical composition of CFM, clover and wheat straw is shown in Table (1).

\section{Dam treatments:}

During the late pregnancy stage, animals in the first group were fed with the control ration without probiotic cultures (G1). While, those in the second group (G2) were given the control ration supplemented with YC (Saccharomyces cerevisiae yeast culture) at a level of $20 \mathrm{~g} / \mathrm{h} / \mathrm{d}$. Animals in the 3rd group (G3) were given the control diet plus LB (Lactobacillus acidophilus) at a level of $20 \mathrm{~g} / \mathrm{h} / \mathrm{d}$, while those in the 4th group (G4) were given the control ration plus $10 \mathrm{~g} / \mathrm{h} / \mathrm{d}$ of $\mathrm{YC}$ and $10 \mathrm{~g} / \mathrm{h} / \mathrm{d}$ of LB. The experimental period lasted from one-month prepartum up to 105 days postpartum.

The YC Diamond V-XPCTM is a yeast culture that contains $1.0 \times 106 \mathrm{CFU}$ of Saccharomyces cerevisiae, it provided from Diamond V Cedar Rapids, IA52404, USA. LB (Probax $\left.{ }^{\circledR}\right)$ was offered from Dugok-Ri, Sinam-Myeon Co Ltd., Yesan-Gun, Chungcheongnam-Do 340-861, Korea it contains $1.0 \times 1010$ CFU (Lactobacillus acidophilus) and Dextrose up to $1 \mathrm{~kg}$. The chemical analysis on dry matter basis of YC and LB is presented in (Table 1).

Table 1. Chemical analysis of different feedstuffs and dietary probiotic cultures (on DM basis)

\begin{tabular}{lccccccc}
\hline \multirow{2}{*}{ Item } & \multirow{2}{*}{ DM } & \multicolumn{6}{c}{ Chemical composition (\%) } \\
\cline { 3 - 8 } & & OM & CP & CF & EE & NFE & ASH \\
\hline CFM & 89.0 & 88.50 & 14.32 & 15.10 & 4.22 & 54.86 & 11.50 \\
Wheat straw & 90.63 & 88.20 & 3.00 & 39.33 & 1.73 & 44.14 & 11.80 \\
Egyptian clover & 17.19 & 87.29 & 13.49 & 23.37 & 1.68 & 48.75 & 12.71 \\
Yeast culture & 92.23 & 94.77 & 33.67 & 6.24 & 10.42 & 44.44 & 5.23 \\
Lactobacillus acidophilus & 93.00 & 91.60 & 25.80 & 12.50 & 10.60 & 42.70 & 8.40
\end{tabular}

$\mathrm{CFM}=$ Concentrate feed mixture; $\mathrm{DM}=$ Dry matter; $\mathrm{OM}=$ Organic matter; $\mathrm{CP}=$ Crude protein; $\mathrm{CF}=\mathrm{Crude}$ fiber; $\mathrm{EE}=\mathrm{Ether}$ extract; NFE=Nitrogen free extract.

\section{Calve management:}

Immediately after buffalo calving (the $1^{\text {st }}$ day post-partum), each calf was helped to suckle its dam for colostrum consumption $(1.5-2 \mathrm{~kg})$ and persist for three consecutive days. After the $3^{\text {rd }}$ post-partum day, each calf was artificially suckled its dam milk twice daily at a rate of $10 \%$ of their body weight for 6 weeks. Then, the amount of milk was weekly decreased by $1 \%$ of live body weight (LBW) up to weaning age (15 wk of age). From 3-15 wk of age, calves were fed ad libitum on the starter and berseem hay. Fresh drinking water was offered at free choice to all calves all day times. Throughout the experimental period, all calves were free of diseases (pneumonia, diarrhea, and enteritis) and no mortality was recorded.

\section{Experimental procedures: \\ Growth performance of calves:}

Live body weight (LBW) of calves was recorded at birth and weaning (15 wk of age). The total body weight gain (TBG) and daily body weight gain (ADG) were calculated. 


\section{Blood and colostrum sampling:}

Blood samples were drawn from the jugular vein from all newborn calves into heparinized test tubes on days 1, 2 and 3 post-partum $3 \mathrm{~h}$ after suckling colostrum for determination of plasma immunoglobulins. Also, blood samples were collected at weaning age into two test tubes (one without and another with anticoagulant). The blood samples were centrifuged at $3000 \mathrm{~g}$ for $15 \mathrm{~min}$ to separate the blood and the plasma, Then the plasma was stored $\left(-20^{\circ} \mathrm{C}\right)$ until biochemical assays.

On the same days, colostrum samples $(50 \mathrm{ml})$ were taken from dam of each calf then stored at $-20 \mathrm{oC}$ till immunoglobulin concentrations assay.

\section{Analytical methods:}

Hematological parameters (packed cell volume, $\mathrm{PCV}$; concentration of hemoglobin, $\mathrm{Hb}$; red blood cell count, RBCs; white blood cell count, WBCs) were measured in the whole blood samples immediately after blood collection. Both RBCs and WBCs were counted using the heamocytometer, while $\mathrm{Hb}$ concentration and PCV were directly determined (Mission ${ }^{\circledR}$ Plus kit, REF C132-3031, USA) according to the method of Henry (2001). Concentrations of different biochemical contents in blood plasma of the calves were measured; total proteins, TP (Henry, 1964), albumin, Alb (Doumas et al., 1971), total lipids, TL (Zollner and Kirsch, 1962), total cholesterol, TC (Richmond, 1973), glucose, GL (Trinder, 1969) and creatinine (Bartles et al., 1972). While globulin (Glb) concentrations were calculated by subtracting albumin from total protein concentration. In addition, the activity of aspartateaminotransferase (AST) and alanineaminotransferase (ALT) were determined calorimetrically using the method as described by Reitman and Frankle (1957).

Total antioxidants capacity (TAC) was determined after the methods of Koracevic et al. (2001). Different types of immunoglobulins (IgG, $\operatorname{IgM}$, and $\operatorname{IgA}$ ) concentrations in samples of colostrum and blood plasma for three consecutive- days post-partum were determined according to Killingsworth and Savory (1972). Blood plasma concentrations of triiodothyronine (T3) were determined by the radio-immuno-assay (RIA). Commercial kit (Coat-A-Count $\left.{ }^{\circledR}-\mathrm{TKT} 31\right)$ by Automatic Mini-Gamma Counter (LKB-1275) as the method of Saunders (1995) was used for T3 determination.

\section{Statistical analysis:}

The obtained data were statistically analyzed according to the SPSS analysis program (SPSS version 15, 2010). Calf data of growth performance, hematological, biochemical components, total antioxidant capacity, enzyme activity, and T3 hormone were statistically analyzed by one-way design. However, data of calf plasma and colostrum immunoglobulins were analyzed as a factorial design (4 dam treatments; DT x 3 sampling days). Duncan Multiple Range Test (Duncan, 1955) was used for detecting the significant differences at $\mathrm{P}<0.05$. Also, Pearson's correlation between immunoglobulins level in blood plasma and colostrum was done using SPSS (2010) program.

\section{RESULTS}

\section{Growth performance of calves:}

Despite of the recorded significantly $(\mathrm{P}<0.05)$ higher birth calf live body weight (LBW) of treatment groups (G2-G4) compared with control (G1) as affected by DT, the same trend was observed at weaning. Calves of treatment groups showed significantly $(\mathrm{P}<0.05)$ higher total $(\mathrm{TBG})$ and daily (ADG) weight gain compared to G1. Relative to a TBG of the control calves, calves in treatment groups showed significantly $(\mathrm{P}<0.05)$ higher $\mathrm{TBG}$ than controls. Generally, calves of G4 (dams treated with a combination of $\mathrm{YC}$ and LB) showed the highest growth performance from birth to weaning, resulting to an increase in total gain by $31.7 \%$, relative to control calves (Table 2).

Table 2. Effect of dam treatment on growth performance of their calves

\begin{tabular}{lcccc}
\hline Traits & G1 & G2 & G3 & G4 \\
\hline Live body weight at birth $(\mathrm{kg})$ & $32.17 \pm 0.40 \mathrm{c}$ & $37.17 \pm 1.40 \mathrm{~b}$ & $37.00 \pm 1.90 \mathrm{~b}$ & $41.50 \pm 0.93 \mathrm{a}$ \\
Live body weight at weaning $(\mathrm{kg})$ & $86.83 \pm 0.40 \mathrm{c}$ & $98.67 \pm 1.73 \mathrm{~b}$ & $100.33 \pm 1.50 \mathrm{~b}$ & $113.50 \pm 3.98 \mathrm{a}$ \\
Total body gain $(\mathrm{kg})$ & $54.67 \pm 0.56 \mathrm{c}$ & $61.50 \pm 0.67 \mathrm{bc}$ & $63.33 \pm 3.15 \mathrm{~b}$ & $72.00 \pm 3.50 \mathrm{a}$ \\
Average daily gain $(\mathrm{kg} / \mathrm{h} / \mathrm{d})$ & $0.52 \pm 0.01 \mathrm{c}$ & $0.59 \pm 0.01 \mathrm{~b}$ & $0.60 \pm 0.03 \mathrm{~b}$ & $0.69 \pm 0.03 \mathrm{a}$ \\
Total gain relative to control & $100.0 \pm 0.00 \mathrm{c}$ & $112.6 \pm 2.12 \mathrm{~b}$ & $116 \pm 6.04 \mathrm{~b}$ & $131.6 \pm 5.64 \mathrm{a}$ \\
\hline
\end{tabular}

G1=Control; G2=Saccharomyces cerevisiae yeast culture (YC); G3=Lactobacillus (LB); G4=Combination (YC + LB). a-c: Means within the same row with different superscripts are significantly different at $\mathrm{P}<0.05$.

\section{Complementary immune response of calves: Effect of dam treatment:}

Comparing to control (G1), DT with combination of $\mathrm{YC}$ and $\mathrm{LB}(\mathrm{G} 4)$ increased $(\mathrm{P}<0.05)$ the concentrations of calf blood plasma $\operatorname{IgG}, \operatorname{IgA}$, and $\operatorname{IgM}$ and in colostrum. The DT with LB (G3) resulted in an increase $(\mathrm{P}<0.05)$ of $\mathrm{IgG}$ in colostrum and $\operatorname{IgA}$ in plasma. However, G2 (YC) had a significant effect only on IgG in colostrum. These findings indicated a beneficial effect of DT with a combination (YC+LB; G4) on levels of $\operatorname{IgG}$, IgA, and IgM in their colostrum and consequently on blood plasma of their calves. Results of immunoglobulins are in association with its levels in colostrum, reflecting highly 
significant and strong correlation coefficients (r) between immunoglobulins in plasma and colostrum, ranging from 0.871 for $\operatorname{IgA}$ in $\mathrm{G} 4(\mathrm{P}<0.01)$ to 0.993 for IgG in $\mathrm{G} 3(\mathrm{P}<0.001$, Table 3$)$.

Table 3. Concentration of immunoglobulins (IgG, IgA and IgM) in blood plasma of buffalo calves and colostrum of their dams.

\begin{tabular}{|c|c|c|c|c|c|c|c|c|}
\hline \multirow[t]{2}{*}{ Item } & \multicolumn{4}{|c|}{ Treatment (T) } & \multicolumn{3}{|c|}{ Sampling day (D) } & \multirow{2}{*}{$\begin{array}{c}\text { P-value } \\
(T * D)\end{array}$} \\
\hline & G1 & G2 & G3 & G4 & D1 & D2 & D3 & \\
\hline \multicolumn{9}{|c|}{ Concentration of $\operatorname{IgG}(\mathrm{g} / \mathrm{dl})$ : } \\
\hline Plasma & $1.47 \pm 0.27 \mathrm{~b}$ & $1.98 \pm 0.28 b$ & $2.11 \pm 0.21 \mathrm{~b}$ & $2.97 \pm 0.30 \mathrm{a}$ & $2.62 \pm 0.25 \mathrm{a}$ & $2.06 \pm 0.26 \mathrm{ab}$ & $1.73 \pm 0.27 b$ & 0.998 \\
\hline Colostrum & $2.31 \pm 0.30 \mathrm{c}$ & $3.11 \pm 0.28 b$ & $3.27 \pm 0.29 \mathrm{ab}$ & $3.99 \pm 0.32 \mathrm{a}$ & $3.83 \pm 0.26 \mathrm{a}$ & $3.07 \pm 0.28 \mathrm{~b}$ & $2.62 \pm 0.27 \mathrm{~b}$ & 0.999 \\
\hline Correlation & $0.965 * * *$ & $0.972 * * *$ & $0.993 * * *$ & $0.982 * * *$ & - & - & - & - \\
\hline \multicolumn{9}{|c|}{ Concentration of $\operatorname{IgA}(\mathrm{g} / \mathrm{dl})$ : } \\
\hline Plasma & $0.14 \pm 0.03 b$ & $0.262 \pm 0.06 \mathrm{ab}$ & $0.293 \pm 0.07 \mathrm{a}$ & $0.366 \pm 0.06 \mathrm{a}$ & $0.417 \pm 0.05 \mathrm{a}$ & $0.237 \pm 0.04 \mathrm{~b}$ & $0.142 \pm 0.02 b$ & 0.971 \\
\hline Colostrum & $0.21 \pm 0.04 \mathrm{~b}$ & $0.359 \pm 0.06 \mathrm{ab}$ & $0.379 \pm 0.08 \mathrm{ab}$ & $0.469 \pm 0.08 \mathrm{a}$ & $0.494 \pm 0.07 \mathrm{a}$ & $0.348 \pm 0.06 \mathrm{ab}$ & $0.220 \pm 0.04 b$ & 0.999 \\
\hline Correlation & $0.935 * * *$ & $0.940 * * *$ & $0.915 * * *$ & $0.871 * *$ & - & - & - & - \\
\hline \multicolumn{9}{|c|}{ Concentration of $\operatorname{IgM}(\mathrm{g} / \mathrm{dl})$ : } \\
\hline Plasma & $0.224 \pm 0.08 b$ & $0.384 \pm 0.08 \mathrm{ab}$ & $0.381 \pm 0.11 \mathrm{ab}$ & $0.686 \pm 0.20 \mathrm{a}$ & $0.669 \pm 0.15 \mathrm{a}$ & $0.379 \pm 0.10 \mathrm{ab}$ & $0.208 \pm 0.05 b$ & 0.904 \\
\hline Colostrum & $0.321 \pm 0.10 \mathrm{~b}$ & $0.514 \pm 0.12 b$ & $0.548 \pm 0.12 b$ & $0.972 \pm 0.20 \mathrm{a}$ & $0.855 \pm 0.15 \mathrm{a}$ & $0.581 \pm 0.12 \mathrm{ab}$ & $0.331 \pm 0.08 \mathrm{~b}$ & 0.998 \\
\hline Correlation & $0.878 * *$ & $0.954 * * *$ & $0.978 * * *$ & $0.983 * * *$ & - & - & - & - \\
\hline
\end{tabular}

G1=Control; G2=Saccharomyces cerevisiae yeast culture (YC); G3=Lactobacillus (LB); G4=Combination (YC + LB). a-c: Means within the same row with different superscripts are significantly different at $\mathrm{P}<0.05$. $\quad * * * \mathrm{P}<0.001 . * * \mathrm{P}<0.01$.

\section{Effect of sampling day:}

Concerning the observed change in immunoglobulins throughout the first three days post-partum, overall mean of $\mathrm{IgG}$ and $\mathrm{IgM}$ concentration in plasma showed significant $(\mathrm{P}<0.05)$ decrease in the third day, while IgA concentration significantly $(\mathrm{P}<0.05)$ decreased on the $2^{\text {nd }}$ day. In colostrum, the overall mean of $\mathrm{IgG}$ concentration significantly $(\mathrm{P}<0.05)$ decreased on the $2^{\text {nd }}$ day, while $\operatorname{Ig} \mathrm{A}$ and $\operatorname{IgM}$ concentrations significantly $(\mathrm{P}<0.05)$ decreased on the $3^{\text {rd }}$ day. These results showed an inconsistent change in immunoglobulins level in colostrum and calf plasma during the first three days post-partum. The reduction in plasma IgA concentration was earlier than in both plasma IgG and IgM. However, in colostrum there was a reduction in $\operatorname{IgG}$ concentration compared to $\operatorname{IgA}$ or IgM (Table 3).

\section{Effect of interaction:}

The statistical analysis revealed an insignificant effect of interaction (DT $x$ sampling day) on all immunoglobulins concentrations of plasma or colostrum (Fig. 1), with similar trends of change in immunoglobulins in plasma or colostrum by advancing sampling day. Generally, on all sampling days, plasma or colostrum immunoglobulins concentrations were higher in all treatment groups as compared to control, being the highest in calves of G4.
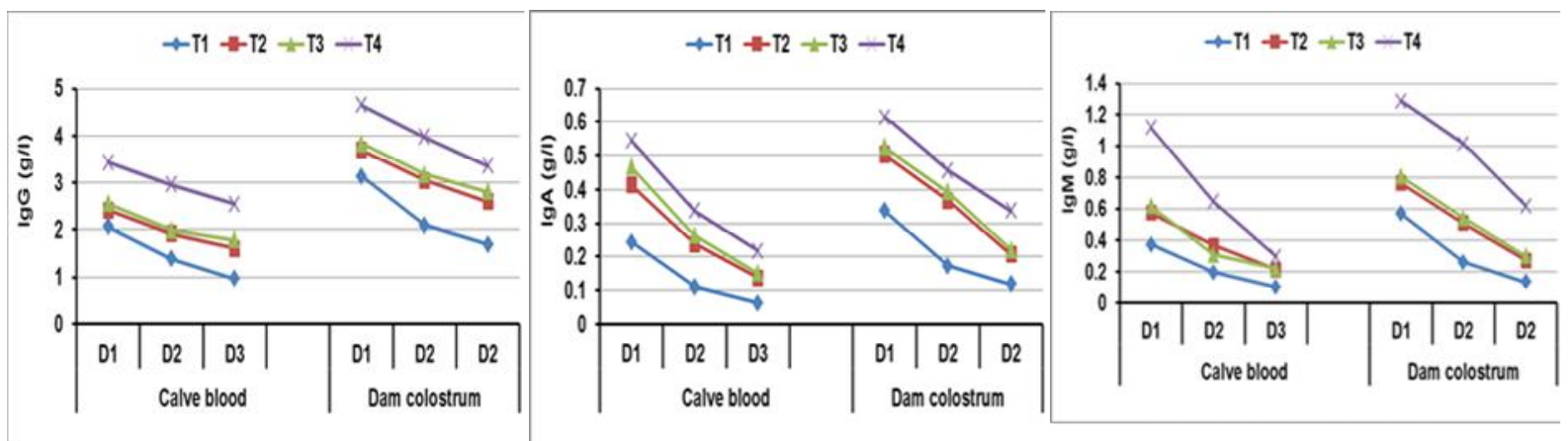

Figure 1. Change in concentration of $\operatorname{IgG}, \operatorname{IgA}$ and $\operatorname{IgM}$ in blood serum of calves and colostrum in experimental groups during consecutive three post-partum days.

\section{Hemato-biochemical parameters of calve blood:}

Hematological parameters, including RBCs count, $\mathrm{PCV}$ percentage and $\mathrm{Hb}$ concentration as well as the concentration of plasma metabolites (TP, Alb, Glb, TL, TC, and GL) significantly $(\mathrm{P}<0.05)$ increased in treatment groups as compared to control one, being the highest in G4. However, WBCs count and creatinine concentration showed an opposite trend (Table 4). 
Table 4. Effect of dam treatment on hemato-biochemical parameters of their calves

\begin{tabular}{lllll}
\hline Prameter & \multicolumn{1}{c}{ G1 } & \multicolumn{1}{c}{ G2 } & \multicolumn{1}{c}{ G3 } & G4 \\
\hline Hematological parameters: & & & \\
RBC $\left(106 / \mathrm{mm}^{3}\right)$ & $7.18 \pm 0.17^{\mathrm{c}}$ & $8.31 \pm 0.18^{\mathrm{b}}$ & $8.11 \pm 0.18^{\mathrm{b}}$ & $9.63 \pm 0.19^{\mathrm{a}}$ \\
WBC $\left(103 / \mathrm{mm}^{3}\right)$ & $11.06 \pm 0.49^{\mathrm{a}}$ & $9.90 \pm 0.53^{\mathrm{ab}}$ & $9.60 \pm 0.53^{\mathrm{ab}}$ & $9.20 \pm 0.54^{\mathrm{b}}$ \\
PCV $(\%)$ & $27.65 \pm 0.82^{\mathrm{c}}$ & $31.85 \pm 0.71^{\mathrm{b}}$ & $30.55 \pm 0.71^{\mathrm{b}}$ & $35.72 \pm 0.53^{\mathrm{a}}$ \\
Hb (g/dl) & $9.20 \pm 0.27^{\mathrm{c}}$ & $10.83 \pm 0.28^{\mathrm{b}}$ & $10.43 \pm 0.28^{\mathrm{b}}$ & $12.46 \pm 0.25^{\mathrm{a}}$ \\
Plasma metabolites: & & & & \\
Total proteins (g/dl) & $4.57 \pm 0.18^{\mathrm{c}}$ & $6.10 \pm 0.22^{\mathrm{b}}$ & $6.00 \pm 0.22^{\mathrm{b}}$ & $8.65 \pm 0.18^{\mathrm{a}}$ \\
Albumin $(\mathrm{g} / \mathrm{dl})$ & $2.54 \pm 0.14 \mathrm{~d}$ & $3.30 \pm 0.09^{\mathrm{c}}$ & $3.90 \pm 0.09^{\mathrm{b}}$ & $5.26 \pm 0.09^{\mathrm{a}}$ \\
Globulin $(\mathrm{g} / \mathrm{dl})$ & $2.03 \pm 0.08^{\mathrm{c}}$ & $2.80 \pm 0.18^{\mathrm{b}}$ & $2.10 \pm 0.18^{\mathrm{c}}$ & $3.39 \pm 0.15^{\mathrm{a}}$ \\
Total lipids $(\mathrm{mg} / \mathrm{dl})$ & $564.43 \pm 6.82^{\mathrm{c}}$ & $605.79 \pm 5.53^{\mathrm{b}}$ & $606.79 \pm 5.53^{\mathrm{b}}$ & $635.14 \pm 6.00^{\mathrm{a}}$ \\
Total cholesterol (mg/dl) & $93.13 \pm 2.75 \mathrm{~d}$ & $108.70 \pm 2.33^{\mathrm{c}}$ & $103.70 \pm 2.33^{\mathrm{b}}$ & $124.29 \pm 2.40^{\mathrm{a}}$ \\
Glucose $(\mathrm{mg} / \mathrm{dl})$ & $54.98 \pm 1.33^{\mathrm{c}}$ & $60.71 \pm 1.77^{\mathrm{b}}$ & $62.71 \pm 1.77^{\mathrm{b}}$ & $87.11 \pm 1.61^{\mathrm{a}}$ \\
Creatinine $(\mathrm{mg} / \mathrm{dl})$ & $1.93 \pm 0.06^{\mathrm{a}}$ & $1.31 \pm 0.04^{\mathrm{b}}$ & $1.37 \pm 0.04^{\mathrm{b}}$ & $0.99 \pm 0.04^{\mathrm{c}}$ \\
\hline
\end{tabular}

G1=Control; G2=Saccharomyces cerevisiae yeast culture (YC); G3=Lactobacillus (LB); G4=Combination (YC + LB). a-c: Means within the same row with different superscripts are significantly different at $\mathrm{P}<0.05$.

Calve blood antioxidant capacity, enzyme activity and triiodothyronine concentrations:

Concentrations of TAC and T3 were significantly $(\mathrm{P}<0.05)$ increased, but AST and ALT activities were significantly $(\mathrm{P}<0.05)$ decreased in treatment groups as compared to control one, being the highest and the lowest in G4, respectively (Table 5).

Table 5. Effect of dam treatment on plasma total antioxidant capacity, transaminases activity and triiodothyronine hormone of their calves

\begin{tabular}{lcccc}
\hline Item & G1 & G2 & G3 & G4 \\
\hline TAC (mmol/l) & $1.96 \pm 0.05^{\mathrm{d}}$ & $2.62 \pm 0.05^{\mathrm{c}}$ & $2.86 \pm 0.05^{\mathrm{b}}$ & $4.37 \pm 0.07^{\mathrm{a}}$ \\
Enzyme activity (IU/l): & & & & \\
alanine-aminotransferase (ALT) & $28.37 \pm 0.26^{\mathrm{a}}$ & $19.95 \pm 0.23^{\mathrm{b}}$ & $18.35 \pm 0.23^{\mathrm{c}}$ & $14.47 \pm 0.26^{\mathrm{d}}$ \\
aspartate-aminotransferase (AST) & $57.71 \pm 0.71^{\mathrm{a}}$ & $35.87 \pm 0.76^{\mathrm{b}}$ & $34.87 \pm 0.76^{\mathrm{b}}$ & $22.42 \pm 0.50^{\mathrm{c}}$ \\
T3 (ng/ml) & $1.36 \pm 0.05 \mathrm{c}$ & $2.12 \pm 0.05 \mathrm{~b}$ & $2.16 \pm 0.05 \mathrm{~b}$ & $3.77 \pm 0.07^{\mathrm{a}}$ \\
\hline
\end{tabular}

G1=Control; G2=Saccharomyces cerevisiae yeast culture (YC); G3=Lactobacillus (LB); G4=Combination (YC + LB); $\mathrm{TAC}=$ Total antioxidant capacity; $\mathrm{T} 3=$ Triiodothyronine. $\mathrm{a}-\mathrm{d}$ : Means within the same row with different superscripts are significantly different at $\mathrm{P}<0.05$.

\section{DISCUSSION}

The main objective of this study was to evaluate the effect of buffalo cow treatment with probiotic cultures such as Saccharomyces cerevisiae yeast culture (YC), Lactobacillus acidophilus (LB), or their combination (LB+YC) during pre- and post-partum period on growth performance, immune response, blood hemato-biochemical parameters, antioxidant capacity, enzyme activity and hormone of their neonatal calves from birth up to weaning. Lactobacillus acidophilus is one of the dominant lactobacilli in the human intestine was widely used as probiotic cultures (Oh et al., 2000). In the literature, several reports indicated positive impact of probiotic cultures on performance and production of cattle, in terms of improving feed intake (Ayad et al., 2013), feed efficiency, growth performance (Lascano et al., 2009), nutrient digestibility coefficients (Wohlt et al., 1991), blood hematology (Agazzi et al., 2014) absorption of some minerals (Cole et al., 1992), metabolic health (Dolezal et al., 2012), mucosal immune system function, and levels of immunoglobulin (Heinrichs et al., 2009), when yeast culture was fed to cattle as well as performance of their calves at birth and during the suckling period (Wafa, 2017). However, some authors found that YC supplementation of primiparous and multiparous Friesian cows had no significant effect on calf birth weight (Mostafa et al., 2014).

The obtained results in this study indicated heavier birth weight calves in all groups of dams treated with YC, LB or their combination than in the group fed with the control diet, which may be attributed to the improvement in overall health status and weight of their dams (Wafa, 2017). In this way, the concentration of immunoglobulins ( $\operatorname{IgG}, \operatorname{IgA}$, and IgM) increased in calf blood plasma or their dams colostrum of treatment groups as compared to control, being the highest in calf plasma and colostrum in $\mathrm{G} 4(\mathrm{YC}+\mathrm{LB})$. The observed significant drop $(\mathrm{P}<0.05)$ in IgG level in colostrum on the 2 nd day reflected insignificant $(\mathrm{P}<0.05)$ reduction in calf plasma $\mathrm{IgG}$ on the 3rd day. Similarly, Erhard et al. (1999) observed decreased immunoglobulins concentrations in calf serum during the first week of 
life and increased later due to auto-synthesis. Although, Murphy et al. (2005) found no correlation between serum IgG concentration in the calf and in the cow, Ježek et al. (2012) recorded a positive relationship of calf serum $\operatorname{IgG}$ and $\operatorname{IgA}$ in the 1 st week with the $\operatorname{IgG}$ concentration in the serum of cows. In this respect, the correlations in the present study, indicating that IgG concentration showed a nearly similar trend in plasma and colostrum in each group. In all groups, colostrum immunoglobulins intakes significantly $(\mathrm{P}<0.01-\mathrm{P}<0.001)$ and strongly correlated with their levels in plasma $\operatorname{IgG}(\mathrm{r}=0.965$ 0.993), $\operatorname{IgA}(\mathrm{r}=0.871-0.940)$ and $\operatorname{IgM}(\mathrm{r}=0.878$ 0.983). In accordance with the present results, Erhard et al. (1999) found a correlation between the concentration of IgG in the colostrum and calf serum. Dolenc (1998) ascertained good association between IgG1, IgG2 and IgM in colostrum and calf blood $(\mathrm{r}=$ 0.91-0.97). Also, Bender and Bostedt (2009) found that IgG and IgM in colostrum significantly correlated with their levels in calf serum at the age of 24 hours.

According to the present results, the highly significant increase in calves blood plasma IgA, IgG and $\operatorname{IgM}$ immediately after birth up to the 3rd dayresulted from increasing immunoglobulin levels in the colostrum of dams fed YC and LB combination diet (G4). These results are in agreement with Fröhdeová et al. (2014), which found that the lower amount of Saccharomyces cerevisiae addition to higher lactating cows led to increasing the level of cows serum IgG and then the level of IgG in serum their calves. Also, similar effects were reported by some previous investigations after the ration supplementation with prebiotics in different species (Franklin et al., 2002; Spearman, 2004). This finding may be due to the synergic effect of both probiotics on intestinal absorption of immunoglobulins in calves immediately after birth. Around calving, cow immune response affected the calf health and its immune response. In bovine, Baines et al. (2011) confirmed that probiotic (Celmanax) increased level of both $\mathrm{IgG}$ and $\operatorname{IgM}$ after parturition then sudden decrease in the level of both $\operatorname{IgG}$ and $\operatorname{IgM}$ occurred during the first three days after parturition either in treated or control group was attributed to transport of immunoglobulins from blood into mammary gland secretion in the period around calving (Heriazon et al., 2011). Also, positive correlation between colostrum quality and $\operatorname{IgG}, \operatorname{IgA}$ and $\operatorname{IgM}$ concentration in calf serum during the first week and with concentration of IgG during the fourth week of age was reported by Ježek et al. (2012). Also, the positive correlations between $\mathrm{IgG}$ and $\mathrm{IgA}$ in the calf serum in the $1^{\text {st }}$ and 4th week of life indicate that calves with the higher Ig concentration in the 1 st week also have a higher Ig level later when they already produce their own immunoglobulin.

The present results are in accordance with Wafa (2017) who showed that dietary adding $40 \mathrm{~g} \mathrm{YC} / \mathrm{h} / \mathrm{d}$ to lactating cows during pre- and post-partum resulted in improving most the hematological parameters of their calves as compared to control and those treated with $20 \mathrm{~g} \mathrm{YC/h} / \mathrm{d}$. The later author indicated a significant increase in $\mathrm{RBCs}, \mathrm{Hb}$ and $\mathrm{PCV}$, as well as an insignificant decrease in calf WBCs leading to improving the immunity of their calves (Anderson et al., 1999). Based on these finding, DT (feeding additives) had a marked effect on calf's hematological parameters (Radkowska and Herbut, 2014).

As proven in the present study, Wafa (2017) reported that DT with $\mathrm{YC}(40 \mathrm{~g} / \mathrm{h} / \mathrm{d})$ significantly $(\mathrm{P}<0.05)$ increased concentrations of serum total proteins, albumin, globulin, total lipids, cholesterol, and glucose, while decreased concentrations of creatinine and triiodothyronine, as well as AST and ALT activity in calf serum as compared to control and those treated with $20 \mathrm{~g} / \mathrm{h} / \mathrm{d}$. Also, Frohdeova et al. (2014) found that serum crude protein concentration in newborn calf markedly increased by feeding their dams on diet supplemented with YC. In our study, increasing total protein concentration in newborn plasma was associated with higher calf levels of immunoglobulins and a better health condition as previously reported by Tothova et al. (2014). Similar results were reported on dairy calves fed with YC supplemented diets (Frohdeova et al., 2014) and in growing lamb treated with in-activated yeast (Ghoneem and Mahmoud, 2014). Also, ElAshry et al. (2003) found that supplementation of Saccharomyces cerevisiae $(5 \mathrm{mg} / \mathrm{h} / \mathrm{d})$ decreased $(\mathrm{P}<0.01)$ plasma ALT and AST than control groups of growing lambs.

Increasing the calf blood total lipids concentration as affected by DT indicated a pronounced relationship of easily digestible components availability in colostrum or milk (Strusinka et al., 1998). In our study, the treatment of dams with the combination of YC and LB had positive effects on calves performance, hematology, metabolites, enzyme activity, thyroid hormone, immunity, and antioxidant capacity more than calves of YC or LB alone. This may be due to more synergetic effects of both treatments on stimulation of beneficial microbiota compared to individual supplementation of probiotic and prebiotic. This combination could improve the survival of the probiotic organism because its specific substrate and readily available for its fermentation, so it resulted in advantages to the host of live micro-organism (Sharma et al., 2018).

Increasing calf growth performance in G4 during the suckling period could be attributed to the milk composition of their dams and improved their immune response which indicates that feeding dams on the combination of LB and YC diet resulted in a marked increase in calf immunity by increasing IgG and reducing $\mathrm{WBC}$ count. Also, this may be due to the significant $(\mathrm{P}<0.05)$ increase in $\mathrm{RBCs}$ count, PCV percentage and $\mathrm{Hb}$ concentration as affected by DT in G4. This improvement was associated with increasing $(\mathrm{P}<0.05)$ protein, lipid, and carbohydrates metabolism (Table 4) that indicating normal kidney function being the best in calves of G4. Furthermore, 
the present results also indicated significant $(\mathrm{P}<0.05)$ increase in total antioxidant capacity, liver function and triiodothyronine of calves from dams which treated with a combination of LB and YC.

\section{CONCLUSION}

In the rations of dams of Egyptian buffalo, addition of supplemental Saccharomyces cerevisiae $(10 \mathrm{~g} / \mathrm{h} / \mathrm{d})$ and Lactobacillus acidophilus $(10 \mathrm{~g} / \mathrm{h} / \mathrm{d})$ combination in the 30 -day pre- to 105 -day postpartum period, could result in enhancing the growth performance, health status, immunity response and antioxidant capacity of newborn calves. Accordingly, DT may produce healthy dairy heifers or bull calves for commercial use and productivity.

\section{REFERENCES}

Agazzi, A., T. Erica, S. Simone, M. Serena, R. Barbara, B. Carla, M.C. Jessica, D. Vittorio, R. Nicola and S. Giovanni, 2014. Effects of speciesspecific probiotic addition to milk replacer on calf health and performance during the first month of life. Ann. Anim. Sci. 14: 101-115.

Anderson, B.H., D.L. Watson and I.G. Colditz, 1999. The effect of dexamethasone on some immunological parameters in cattle. Vet. Res. Commu. 23: 399-413.

Ayad, M.A., B. Benallou, M.S. Saim, M.A. Smadi and T. Meziane, 2013. Impact of feeding yeast culture on milk yield, milk components, and blood components in Algerian dairy herds. J. Veterinar. Sci. Technol. 4(135): 2-9.

Baines, D., C. Elrod, J. Oppy and S. Jalukar, 2011. A probiotic Celmanax decreases Escherichia coli 0157:H7 colonization of bovine cells and feed associated cytotoxicity in vitro. BMC Res. Notes. 4: 110

Bartles, H., M. Bohmer and C. Heirli, 1972. Serum kreatinin bestimmung ohne enteiweissen. Clin. Chem. Acta., 37: 193.

Bayram, B., V. Aksakal, I. Turan, S. Demir, H. Mazlum and I. Cosar, 2016. Comparison of immunoglobulin (IgG, IgM) concentrations in calves raised under organic and conventional conditions. Ind. J. Anim. Res. 50: 995-999.

Bender, P. and H. Bostedt, 2009. Determination of IgG and IgM levels in sera of newborn calves until the 10th day of life by ELISA and description of their correlation to total plasma protein concentration and GGT activity. Deut. Tierä. Woche. 116: 44-52.

Cole, N.A., C.W. Purdy and D.P. Hutcheson, 1992. Influences of yeast culture on feeder calves and lambs. J. Anim. Sci, 70: 1682-1690.

Dawson, K.A. 1993. Current and future role of live yeast in animal production: A review of research over the last six years. In: T. P. Lyons (ed) Biotechnology in the Feed Industry Nicholasville, Kentucky: Alltech Technical Publications pp. 269-291.
Dolenc, A. 1998. Vpliv različno dolge suhe dobe krav na vsebnost imunoglobulinov $\mathrm{v}$ mlezivu. Doktorska disertacija. Ljubljana, Veterinarska fakulteta, $94 \mathrm{p}$.

Dolezal, P., J. Dolezal, K. Szwedziak, J. Dvoracek, L. Zeman, M. Tukiendorf and Z. Havlicek, 2012. Use of yeast culture in the TMR of dairy Holstein cows. Iran. J. Appl. Anim. Sci., 2: 51-56.

Doumas, B., W. Watson and H. Biggs, 1971. Albumin standards and measurements of serum with bromocresol green. Clin. Chem. Acta. 31: 87-96.

Duncan, D.B. 1955. Multiple ranges and multiple F test. Biome. 11: 1-42.

El-Ashry, M.A., A.M. Fayed, K.M. Youssef, F.A. Salem and A.A. Hend, 2003. Effect of feeding flavomycin or yeast as feed supplement on lamb performance in Sinai. Egy. J. Nut. Fee. 6(Special Issue), 1009-1022.

Erhard, M.H., P. Amon, M. Younana, Z. Ali and M. Stangassinger, 1999. Absorption and synthesis of immunoglobulins $G$ in newborn calves. Rep. Dom. Anim. 34: 173-175.

Franklin, S.T., K.E. Newman and M.C. Newman, 2002. Evaluation of mannan oligosaccharide on the immune status of dairy cows and their calves. J. Anim. Sci. 80 (Suppl), 192.

Frizzo, L.S., L.P. Soto, E. Bertozzi, M.V. Zbrun, M.L. Signorini, G.R. Sequeira, A. Rodriguez and M.R. Rosmini, 2011. Intestinal populations of Lactobacilli and coliforms after in vivo Salmonella Dublin challenge and their relationship with microbial translocation in calves supplemented with lactic acid bacteria and lactose. Anim. Fee. Sci. Techno. 170: 12-20.

Fröhdeová, M., V. Mlejnkova1, K. Lukešova1 and P. Doležal, 2014. Effect of prepartum supplementation of yeast culture (saccharomyces cerevisiae) on biochemical parameters of dairy cows and their newborn calves. Act. Uni. Agri. Et Silvi. Mend. Bru. 62: 897-904.

Ghoneem, W.M.A. and A.E.M. Mahmoud, 2014. Effect of in-activated and dried yeast on productive performance of Barki lambs. Asi. J. Anim. Vete. Adva. 9: 664-673.

Heinrichs, A., C. Jones, J. Elizondo-Salazar and S. Terrill, 2009. Effects of a prebiotic supplement on health of neonatal dairy calves. Livest. Sci., 125: 149-154.

Henry, J.B. 2001. Clinical Diagnosis and Management by Laboratory Methods. Twent. Edit. Page 485.

Henry, R.J. 1964. Proteins. In: Clinical Chemistry Principles and Technics, 1st ed., Chapter 11: pp.173-253, Harper \& Row Publishers, New York.

Heriazon, A., K. Hamilto, J. Huffma, B.N. Wilkie, W. Sears, M. Quinton and B.A. Mallard, 2011. Immunoglobulin isotypes of lactating Holstein cows classified as high, average, and low type -1 or -2 immune responders. Vet. Immunol. Immunopa. 144: 259-269. 
Hutjens, M.F. 2003. Economics of Feed Additives. Penn State Dairy Cattle Nutrition Workshop. dasweb.psu.edu/pdf/hutjens1.pdf.

Ježek, J., T. Malovrh and K. Martina, 2012. Serum immunoglobulin (IgG, IgM, IgA) concentration in cows and their calves. 20th Int. Symp. "Animal Science Days", Kranjska gora, Slovenia, Sept. $19^{\text {th }}-21^{\text {st }}, 2012$.

Kawakami, S.I., T. Yamada, N. Nakanishi and Y. Cai, 2010. Feeding of lactic acid bacteria and yeast on growth and diarrhea of Holstein calves. J. Anim. Vet. Adv. 9: 1112-1114.

Kearl, L.C. 1982. Nutrient requirements of ruminants in developing countries. Utah State Univ., Logan, Utah.

Killingsworth, L.M. and J. Savory, 1972. Manual Nephelometric methods for immunochemical determination of immunoglobulins IgG, IgA and IgM. Clin. Chem, 18: 335-339.

Koracevic, D., G. Koracevic, V. Djordjevic, S. Andrejevic and V. Cosic, 2001. Method for the measurement of antioxidant activity in human fluids. J. clin. Patho. 54: 356-361.

Lascano, G.J., A.J. Heinrichs and J.M. Tricarico, 2012. Substitution of starch by soluble fiber and Saccharomyces cerevisiae dose response on nutrient digestion and blood metabolites for precision-fed dairy heifers. J. Dai. Sci. 95: 32983309.

Lascano, G.J., G.I. Zanton, M.F. Suarez-Mena and A.J. Heinrichs, 2009. Effect of limit feeding highand low-concentrate diets with Saccharomyces cerevisiae on digestibility and on dairy heifer growth and first-lactation performance. J. Dai. Sci. 92: 5100-5110.

Mostafa, T.H., F.A. Elsayed, M.A. Ahmed and M.A. Elkholany, 2014. Effect of using some feed additives (two-probiotics) in dairy cow rations on production and reproductive performance. Egy. J. Anim. Prod. 51: 1-11.

Murphy, B.M., M.J. Drennan, F.P. O’Mara and B. Earley, 2005. Cow serum and colostrum immunoglobulin (IgG1) concentration of five suckler cow breed types and subsequent immune status of their calves. Iris. J. Agri. Fo. Res. 44: 205-213.

Oh, S., S.H. Kim and R.W. Worobo, 2000. Characterization and purification of a bacteriocin produced by a potential probiotic culture, Lactobacillus acidophilus 30SC. J. Dairy. Sci., 83: 2747-2752.

Radkowska, I. and E. Herbut, 2014. Hematological and biochemical blood parameters in dairy cows depending on the management system. Anim. Sci. Pap. Rep. 32: 317-325.

Reitman, S. and M. Frankle, 1957. A colorimetric method for determination of serum oxaloactic and glutamic pyruvic tranaminase. Anim. Clin. Pathol. J. 16: 28-56.

Richmond, W. 1973. Preparation and properties of a cholesterol oxidase from Nocardia sp. and its application to the enzymatic assay of total cholesterol in serum. Clin. Chem. 19: 1350-1356.

Saunders, W.B. 1995. Tietz NW, editor. Clinical guide to laboratory tests. 3rd ed. Philadelphia, 612.

Sharma, A.N., S. Kumar and A.K. Tyagi, 2018. Effects of mannan-oligosaccharides and Lactobacillus acidophilus supplementation on growth performance, nutrient utilization and faecal characteristics in Murrah buffalo calves. J. Anim. Physi. Anim. Nutr. 102: 679-689.

Šlosarkova, S., P. Fleischer, O. Pěnkava and M. Skřrivanek, 2011. Zajištěni kolostralni imunity u novorozenych telat dojeneho skotu a ověřovani jejiurovně $\mathrm{v}$ chovatelske a veterinarni praxi. Certifikovana metodika. Brno: Veterinarni a farmaceuticka univerzita Brno.

Soberon, F. and M.E. Van Amburgh, 2013. The effect of nutrient intake from milk or milk replacer of preweaned dairy calves on lactation milk yield as adults:a meta-analysis of current data. J. Anim. Sci. 91: 706-712.

Soderholm, J.D. and M.H. Perdue, 2001. Stress and the gastrointestinal tract II. Stress and intestinal barrier function. Amer. J. Physio. Gastro. Liv. Physio. 280: G7-G13.

Spearman, K.R. 2004. Effect of mannan oligosaccharide on the immune status of mares and their foals. Th. Mast. Deg. Sci. Uni. Flor.

SPSS: Copyright ${ }^{\circledR}$ SPSS Inc., 2010. Version 15.

Strusinka, D., S. Iwanska and B. Pysera, 1998. The effect of digest acid on growth rate and some blood parameters in calves. J. Anim. Fee. Sci. 7: 217-221.

Tothova, C., O. Nagy and G. Kovač, 2014. Relationship between some variables of protein profile and indicators of lipomobilization in dairy cows after calving. Arch. Tierz. 57: 1-9.

Trinder, P. 1969. Determination of blood serum glucose. Ann. Clin. Biochem. 6: 24.

Wafa, W. M. 2017. Immune Response and Some Blood Constituents of Calves Produced From Primi- And Multi-Parous Friesian Cows Fed Yeast Culture. J. Anim. Poul. Prod. Mansoura Univ. 8: 213-219.

Wohlt, J.E., A.D. Finkelstein and C.H. Chung, 1991. Yeast culture to improve intake, nutrient digestibility and performance by dairy cattle during early lactation. J. Dairy. Sci. 74: 13951400.

Zollner, N. and K. Kirsch, 1962. Determination of total lipids. Z. Ges. Exp. Med. 135, 545. 
تأثير معاملة أمهات الجاموس بالبروبيوتيك علي أداء النمو والإستجابة المناعية ومكونات الام لمو اليدها حليثة الولادة حمدي عبدالله النجار'، عبد العزيز محمد الحايس"، محمد صبحي فراج"

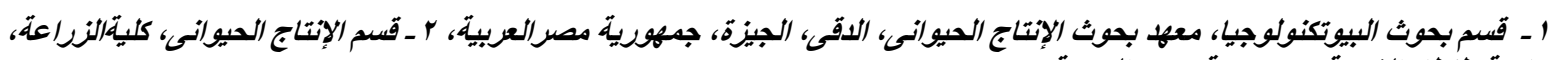
جامعة طنطا، الغربية، جمهورية مصر العربية

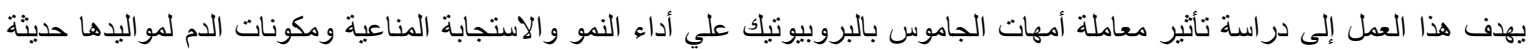

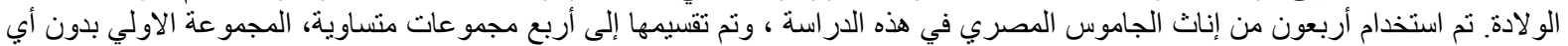

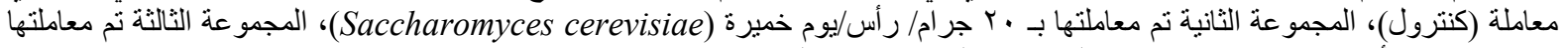

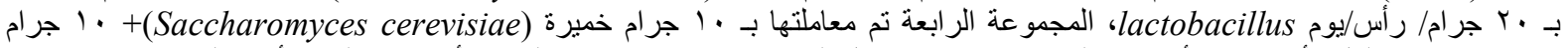

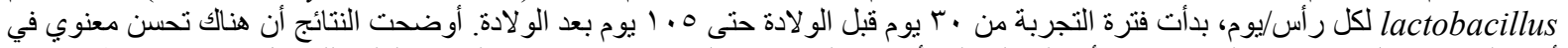

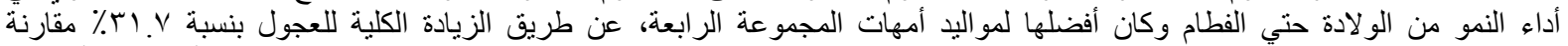

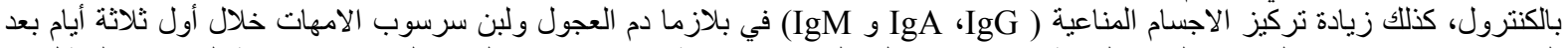

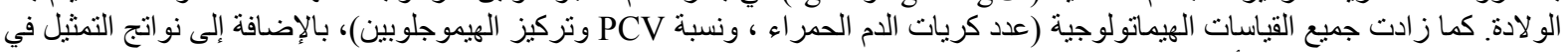

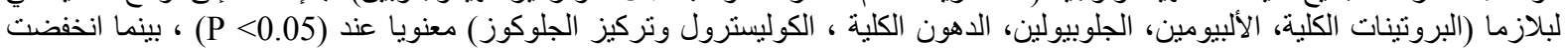

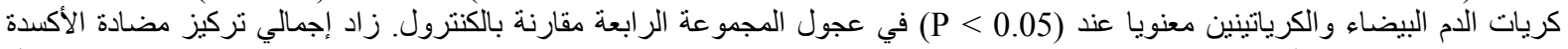

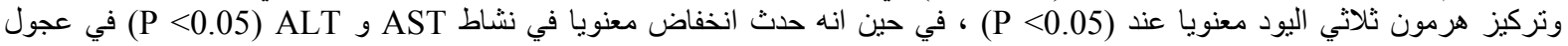

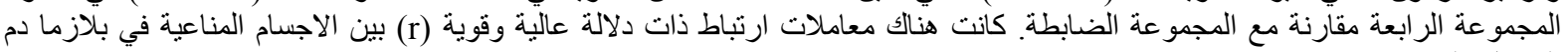

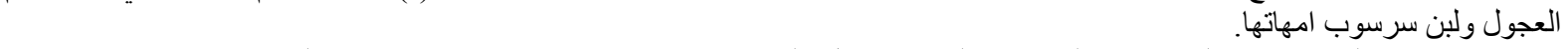

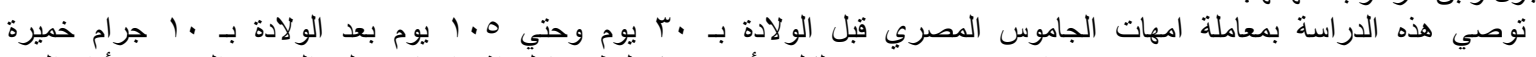

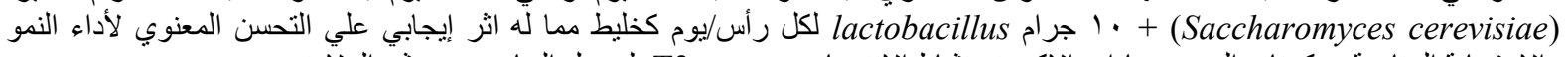
و الاستجابة المناعية ومكونات الام ومضادات الاكسدة ونثاط الانزيمات و هرمون T3 لعجول الجاموس حديثي الو لادة. 